(c) American Dairy Science Association, 2006.

\title{
Slow-Release Urea and Highly Fermentable Sugars in Diets Fed to Lactating Dairy Cows ${ }^{1}$
}

\author{
G. L. Golombeski, ${ }^{2}$ K. F. Kalscheur, ${ }^{3}$ A. R. Hippen, and D. J. Schingoethe \\ Dairy Science Department, South Dakota State University, Brookings 57007
}

\begin{abstract}
This experiment was designed to test the inclusion of highly fermentable sugars (FS) in dairy rations and their interactions with a slow-release urea (SU) product. The FS are a blend of liquid coproducts from the corn milling and cheese industries, and the SU is calcium chloride urea. Eight multiparous and 4 primiparous Brown Swiss cows ( $117 \pm 46$ d in milk) were blocked by parity and utilized in a multiple Latin square design. Basal diets were formulated for $16.6 \%$ crude protein and $1.55 \mathrm{Mcal} / \mathrm{kg}$ of net energy for lactation and contained $35 \%$ of dietary dry matter as corn silage, $15 \%$ alfalfa hay, $34 \%$ of a concentrate mix containing varying proportions of ground shelled corn and soybean meal, and $16 \%$ of a constant concentrate premix. The premix consisted of equal proportions of corn distillers grains, soybean hulls, expeller soybean meal, vitamins, and minerals across all diets. Diets contained either no supplemental FS (NFS) or FS (8.64\% RationMate) and either no SU (NSU) or SU (0.61\% Ruma Pro) in a $2 \times 2$ factorial arrangement of treatments. Feeding FS tended to decrease milk production compared with feeding NFS. Milk fat percentage was increased for cows fed FS compared with NFS. Feeding SU decreased dry matter intake and increased feed efficiency compared with cows fed NSU. Dietary treatment had no effect on energy-corrected milk, milk fat yield, milk protein percentage, or milk urea N. Feeding FS increased the molar proportion of ruminal butyrate and decreased the molar proportion of propionate; however, no other effects were observed on ruminal fermentation. No interactions between FS and SU were observed. It was concluded that the replacement of corn and soybean meal with dietary FS increased milk fat percentage and that the replacement of soybean meal with SU significantly improved feed efficiency.
\end{abstract}

\footnotetext{
Received October 21, 2005.

Accepted June 27, 2006.

${ }^{1}$ Published with the approval of the director of the South Dakota Agricultural Experiment Station as Publication Number 3528 of the Journal Series.

${ }^{2}$ Current address: Department of Animal Science, University of Minnesota, St. Paul 55108.

${ }^{3}$ Corresponding author: kenneth.kalscheur@sdstate.edu
}

Key words: feed efficiency, fermentable sugar, milk fat, slow-release urea

\section{INTRODUCTION}

Feeding coproducts of the agricultural processing industry to lactating cows is of great interest to dairy producers, especially with increased availability and lower costs of corn milling coproducts. Two such coproducts available as dairy feed supplements are whey permeate and corn steep liquor blended into a single liquid feed product. Both coproducts contain highly fermentable sugars (FS). Whey permeate is a coproduct of the cheese industry and is generated when whey is deproteinized and partially delactosed. Corn steep liquor is a coproduct of the corn wet milling industry and is formed by condensation of steep water. Although the production effects of feeding whey to lactating dairy cattle are well documented (Schingoethe, 1976), knowledge of the effects of feeding steep liquor to dairy cattle are limited.

Use of NPN as a protein replacement is also attractive in dairy cattle diets because of its low cost compared with true protein feeds. It has been $40 \mathrm{yr}$ since Virtanen (1966) demonstrated that ruminants can convert NPN to milk protein, but the practice of feeding urea to lactating dairy cows is used with caution. The reluctance to feed urea in dairy diets is related to the potential problems such as poor feed intake, depressed milk fat, and even death by toxicity (Huber and Kung, 1981). These problems are a result of the rapid conversion of urea to ammonia in the rumen. Alternatively, slow ruminal-release urea (SU) may be used without the detrimental effects demonstrated by regular urea. A form of SU is urea bound to calcium chloride. In an in vitro study, Cass and Richardson (1994) observed that calcium chloride-bound urea reduced ammonia $\mathrm{N}$ release and had a degradation rate that was intermediate between urea and cottonseed meal.

Furthermore, research conducted by Casper and Schingoethe (1986) suggested that diets high in N might benefit from addition of a highly fermentable carbohydrate source. In response, this study was designed to evaluate the interaction of SU and FS on feed 
intake, milk yield, and milk composition of lactating dairy cows.

\section{MATERIALS AND METHODS}

\section{Animals, Diets, and Sampling}

Twelve lactating Brown Swiss cows averaging 117 DIM (SD $=46$ ) were used in a multiple Latin square design with 28 -d periods. Multiparous cows $(n=8)$ were randomly assigned to 2 Latin squares and primiparous cows $(n=4)$ were assigned to the remaining square. Diets were fed as a TMR formulated to be isonitrogenous and isocaloric (16\% CP and $1.55 \mathrm{Mcal} / \mathrm{kg}$ of $\mathrm{NE}_{\mathrm{L}}$ ) and consisted of $35 \%$ (DM basis) corn silage, $15 \%$ alfalfa hay, and $50 \%$ of the respective concentrate mixtures (Table 1). Treatment diets were formulated to contain either no supplemental FS (NFS) or FS $(8.64 \%$ RationMate, Midwest Ag Enterprises, Marshall, MN), which partially replaced corn and soybean meal, and either no SU (NSU) or SU (0.61\% Ruma Pro, XF Enterprises, Hereford, TX), which partially replaced soybean meal, in a $2 \times 2$ factorial arrangement of treatments. RationMate is a formula of whey permeate and corn steep liquor blended into a single liquid feed product (Table 2). Ruma Pro is a liquid calcium chloride-bound urea with slow-release properties. Total sugars were calculated to be 5.65 and $4.05 \%$ (DM basis) for the FS and NFS diets, respectively, using the CPM Dairy ration balancing software (Version 3; Cornell University, Ithaca, NY; University of Pennsylvania, Kennett Square, PA; and William H. Miner Agricultural Research Institute, Chazy, NY). Cows were housed in a free-stall barn at the South Dakota State University Dairy Teaching and Research Center. Animal care and use was according to a protocol approved by the South Dakota State University Institutional Animal Care and Use Committee.

Cows were individually fed for ad libitum intake once daily $(0800 \mathrm{~h})$ using Calan Broadbent individual animal feeders (American Calan, Inc., Northwood, NH). Orts were weighed once daily and diet offered was adjusted to ensure $10 \%$ feed refusal. Weeks 1 and 2 of each period were used for adjustment to diets, and wk 3 and 4 for data collection. Samples of diets were collected for 3 consecutive days during the last week of each experimental period and stored at $-20^{\circ} \mathrm{C}$ until analysis.

Ruminal fluid was sampled approximately $3 \mathrm{~h}$ postfeeding via esophageal tube on 2 consecutive days during the last week of each experimental period. Ten milliliters of fresh rumen fluid was placed into a scintillation vial containing $2 \mathrm{~mL}$ of $25 \%$ metaphosphoric acid. Samples were frozen at $-20^{\circ} \mathrm{C}$ until needed for ruminal VFA and ammonia analysis.
Table 1. Ingredient and nutrient composition of the experimental $\operatorname{diets}^{1}$

\begin{tabular}{|c|c|c|c|c|}
\hline \multirow[b]{2}{*}{ Item } & \multicolumn{2}{|c|}{ NSU } & \multicolumn{2}{|c|}{ SU } \\
\hline & NFS & FS & NFS & FS \\
\hline & & 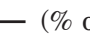 & $\mathrm{DM})$ & \\
\hline \multicolumn{5}{|l|}{ Ingredient composition } \\
\hline Alfalfa hay & 15.0 & 15.0 & 15.0 & 15.0 \\
\hline Corn silage & 35.0 & 35.0 & 35.0 & 35.0 \\
\hline Corn grain, ground & 25.5 & 19.8 & 27.7 & 21.8 \\
\hline Soybean meal, $44 \% \mathrm{CP}$ & 8.5 & 5.6 & 5.8 & 2.9 \\
\hline Dried distillers grains & 7.5 & 7.5 & 7.5 & 7.5 \\
\hline Soybean hulls & 3.0 & 3.0 & 3.0 & 3.0 \\
\hline Expellers soybean meal ${ }^{2}$ & 3.0 & 3.0 & 3.0 & 3.0 \\
\hline Fermentable sugars $^{3}$ & - & 8.6 & - & 8.6 \\
\hline Slow-release urea ${ }^{4}$ & - & - & 0.61 & 0.61 \\
\hline Limestone & 0.81 & 0.81 & 0.81 & 0.81 \\
\hline Salt & 0.48 & 0.48 & 0.48 & 0.48 \\
\hline Sodium bicarbonate & 0.57 & 0.57 & 0.57 & 0.57 \\
\hline Magnesium oxide & 0.17 & 0.18 & 0.17 & 0.17 \\
\hline Mineral and vitamin premix ${ }^{5}$ & 0.29 & 0.29 & 0.29 & 0.29 \\
\hline Vitamin $\mathrm{E}^{6}$ & 0.05 & 0.05 & 0.05 & 0.05 \\
\hline \multicolumn{5}{|l|}{ Nutrient composition } \\
\hline $\mathrm{DM}, \%$ & 53.9 & 53.0 & 52.9 & 52.2 \\
\hline $\mathrm{CP}$ & 16.3 & 15.9 & 16.5 & 15.7 \\
\hline Soluble CP & 5.7 & 6.0 & 6.6 & 6.5 \\
\hline $\mathrm{RDP}^{7}$ & 10.2 & 10.5 & 10.6 & 11.0 \\
\hline $\mathrm{RUP}^{7}$ & 6.4 & 6.1 & 6.0 & 5.7 \\
\hline $\mathrm{NE}_{\mathrm{L}},{ }^{7} \mathrm{Mcal} / \mathrm{kg}$ & 1.55 & 1.55 & 1.56 & 1.55 \\
\hline $\mathrm{ADF}$ & 19.4 & 20.0 & 18.5 & 20.0 \\
\hline NDF & 30.9 & 31.1 & 28.9 & 29.7 \\
\hline $\mathrm{NFC}^{8}$ & 42.0 & 42.0 & 43.2 & 43.1 \\
\hline Starch & 26.8 & 24.0 & 27.8 & 24.7 \\
\hline Ether extract & 3.81 & 3.65 & 3.85 & 3.51 \\
\hline Ash & 6.98 & 7.35 & 7.56 & 8.00 \\
\hline $\mathrm{Ca}$ & 0.74 & 0.82 & 0.83 & 0.86 \\
\hline $\mathrm{P}$ & 0.35 & 0.46 & 0.35 & 0.45 \\
\hline $\mathrm{Mg}$ & 0.39 & 0.42 & 0.39 & 0.42 \\
\hline $\mathrm{K}$ & 1.26 & 1.42 & 1.21 & 1.37 \\
\hline $\mathrm{S}$ & 0.27 & 0.35 & 0.28 & 0.34 \\
\hline
\end{tabular}

${ }^{1} \mathrm{NSU}=$ No slow-release urea; $\mathrm{SU}=$ slow-release urea; $\mathrm{FS}=$ fer mentable sugar; NFS = no fermentable sugar.

${ }^{2}$ Soyplus (West Central Soy, Ralston, IA).

${ }^{3}$ RationMate (Midwest Ag Enterprises, Marshall, MN).

${ }^{4}$ Ruma Pro (XF Enterprises, Hereford, TX).

${ }^{5}$ Contained $4.64 \% \mathrm{Ca}, 10.3 \% \mathrm{Mg}, 4,783 \mathrm{ppm} \mathrm{Fe}, 4,857 \mathrm{ppm} \mathrm{Cu}, 122$ ppm Co, 17,793 ppm Mn, 26,556 ppm Zn, 408 ppm I, 144 ppm Se, $545,000 \mathrm{IU} / \mathrm{kg}$ vitamin A, 109,000 IU/kg vitamin D, and 2,181 IU/kg vitamin E (Land O' Lakes, Inc; St. Paul, MN).

${ }^{6}$ Contained 20,000 IU of vitamin E/kg.

${ }^{7}$ Calculated using NRC (2001).

${ }^{8} \mathrm{NFC}=100-(\% \mathrm{NDF}+\% \mathrm{CP}+\%$ ether extract $+\%$ ash $)$.

Cows were milked at 0600,1400 , and $2100 \mathrm{~h}$ with individual milk weights recorded at each milking. Milk from individual cows was sampled at each milking for 3 consecutive days during wk 4 of each experimental period and composited into daily samples before analysis of true protein, fat, lactose, MUN, and SCC.

Body weights were recorded on 3 consecutive days at the start of the experiment and at the end of each period. Body condition was scored by 3 separate individuals 
Table 2. Nutrient composition of fermentable sugars product

\begin{tabular}{lc}
\hline Nutrient & \\
\hline DM, \% & 48.5 \\
CP, \% of DM & 22.0 \\
Soluble CP, \% of DM & 20.0 \\
Starch, \% of DM & 2.54 \\
Total sugar, \% of DM & 24.1 \\
Lactose, \% of DM & 23.5 \\
Ether extract, \% of DM & 1.91 \\
Ca, \% of DM & 0.74 \\
P, \% of DM & 2.09 \\
K, \% of DM & 3.84 \\
Mg, \% of DM & 0.57 \\
S, \% of DM & 1.32 \\
Na, \% of DM & 1.98 \\
Cl, \% of DM & 2.70 \\
Zn, ppm & 53 \\
Cu, ppm & 8 \\
Mn ppm & 20 \\
Fe, ppm & 107 \\
\hline
\end{tabular}

(Wildman et al., 1982) at the beginning of the experiment and at the end of each period.

\section{Laboratory Analysis}

Samples of diets were made into composites by period and dried at $55^{\circ} \mathrm{C}$ in a Despatch oven (style V-23; Despatch Oven Co., Minneapolis, MN) for $24 \mathrm{~h}$ and ground through a 4-mm screen of a Wiley mill (model 3; Arthur H. Thomas Co., Philadelphia, PA). Samples were reground (Brinkman ultracentrifuge mill, Brinkman Industries Co., Westbury, NY) through a 1-mm screen. Subsamples of feed composites were dried at $105^{\circ} \mathrm{C}$ for $24 \mathrm{~h}$ to correct to $100 \% \mathrm{DM}$. Composites were analyzed for DM, Kjeldahl N, ether extract, and ash according to AOAC methods (AOAC, 1997). Neutral detergent fiber and $\mathrm{ADF}$ were measured using the Ankom A200 (Ankom Technology Corp., Fairport, NY) filter bag technique. Determinations of ADF were according to AOAC (1997; method 973.18 C) and NDF according to Van Soest et al. (1991) with the addition of $4 \mathrm{~mL}$ of $\alpha$-amylase and $20 \mathrm{~g}$ of sodium sulfite. Soluble $\mathrm{CP}$ was analyzed as described by Licitra et al. (1996). Dietary samples were composited across periods and analyzed by Dairyland Laboratories (Arcadia, WI) for starch, ether extract, and minerals. Starch was measured as dextrose after treating samples with glucoamylase using a YSI 2700 Select Biochemistry Analyzer (Application Note \#319, Yellow Springs, OH) and ether extract by AOAC (1997). Minerals were quantified according to AOAC methods (1997; method 985.01) using an inductively coupled plasma spectrometer (Thermo Jarrell Ash, Franklin, MA).

A composite sample across all 4 periods of the FS product was analyzed for DM, CP, soluble CP, starch, ether extract, and minerals as described above. Another composite sample of the FS was sent to Midwest Laboratories, Inc. (Omaha, NE) for lactose and total sugar concentration by hot water extraction according to AOAC (1997, method 942.20) using a HPLC (Waters Corporation, Milford, MA) equipped with a refractive index detector and a Keystone $\mathrm{NH}_{2}$ carbohydrate column with a flow rate of $1.5 \mathrm{~mL} / \mathrm{min}$ of $0.01 \mathrm{~N} \mathrm{H}_{2} \mathrm{SO}_{4}$.

Heart of America DHI Laboratory (Manhattan, KS) conducted milk composition analysis according to approved procedures of AOAC (1997). Milk true protein, fat, and lactose were determined using near-infrared spectroscopy (Bentley 200 Infrared Milk Analyzer; Bentley Instruments, Chaska, MN). Concentration of MUN was determined using chemical methodology based on a modified Berthelot reaction (ChemSpec 150 Analyzer; Bentley Instruments), and somatic cells were counted using a flow cytometer laser (Somacount 500; Bentley Instruments). Energy-corrected milk was calculated as follows (NRC, 2001): ECM $(\mathrm{kg} / \mathrm{d})=$ milk yield $(\mathrm{kg} / \mathrm{d}) \times[(0.0929 \times$ percent fat $)+(0.0563 \times$ percent true protein $)+(0.0395 \times$ percent lactose $)]$ divided by 0.749 $\mathrm{NE}_{\mathrm{L}}(\mathrm{Mcal} / \mathrm{kg})$, the assumed energy concentration of milk.

Ruminal samples were thawed and centrifuged at $7,600 \times g$ for $15 \mathrm{~min}$. Ammonia concentrations were determined following the procedure of Broderick and Kang (1980). Concentrations of VFA were measured by gas chromatography (model 6890; Hewlett-Packard Palo Alto, CA) using a flame-ionization detector. Volatile fatty acids were separated on a $15 \mathrm{~m} \times 0.25 \mathrm{~mm}$ i.d. capillary column (Nukol, 17926-01C; Supelco, Inc., Bellefonte, PA) and the split ratio in the injector port $\left(250^{\circ} \mathrm{C}\right)$ was $100: 1$ with a flow of $1.3 \mathrm{~mL} / \mathrm{min}$ of $\mathrm{He}$. Column and detector temperatures were maintained at 130 and $225^{\circ} \mathrm{C}$, respectively.

\section{In Situ Study}

In a supplemental experiment, 2 ruminally cannulated, mid- to late-lactation cows were used to determine ruminal degradability characteristics of DM and CP for each TMR diet, FS, and SU. Cows were housed in individual pens equipped with feeders and clean water. Cows were fed once daily for ad libitum intake of a total mixed diet composed of $21.4 \%$ alfalfa hay, $26.3 \%$ corn silage, $16.6 \%$ high moisture corn, and approximately $35 \%$ of a concentrate mix (DM basis) that contained ground corn and other micro ingredients (Table 3 ). In situ measurements were taken at $0,0.5,1,1.5,2,4,6,8$, $12,16,24$, and $36 \mathrm{~h}$. To measure ruminal degradability characteristics of the FS and SU products separately and together, these products were inoculated onto dry ground wheat straw at a ratio of 2.5:1 on a DM basis 
Table 3. Composition of diet fed to cows during the in situ study

\begin{tabular}{|c|c|}
\hline Item & $\%$ of $\mathrm{DM}$ \\
\hline Corn silage & 26.3 \\
\hline Alfalfa hay & 21.4 \\
\hline Corn, rolled high moisture & 16.7 \\
\hline Corn, distillers wet & 5.97 \\
\hline Whole cottonseed & 8.96 \\
\hline Corn, shelled ground & 7.29 \\
\hline Liquid supplement $^{1}$ & 4.06 \\
\hline Expellers soybean meal ${ }^{2}$ & 4.43 \\
\hline Porcine meat and bone meal & 1.19 \\
\hline Fish meal, menhaden & 0.75 \\
\hline Rumen bypass fat $^{3}$ & 0.80 \\
\hline Limestone & 0.58 \\
\hline Sodium bicarbonate & 0.54 \\
\hline Salt & 0.41 \\
\hline Dairy micro premix ${ }^{4}$ & 0.21 \\
\hline Yeast culture $^{5}$ & 0.19 \\
\hline $\mathrm{MgO}$ & 0.16 \\
\hline Zn methionine ${ }^{6}$ & 0.05 \\
\hline Vitamin E premix ${ }^{7}$ & 0.02 \\
\hline
\end{tabular}

${ }^{1}$ Energizer 4-19W (Quality Liquid Feeds, Dodgeville, WI).

${ }^{2}$ SoyPlus (West Central Soy, Ralston, IA). $\mathrm{NJ})$

${ }^{3}$ Megalac-R (Arm \& Hammer, Animal Nutrition Group, Princeton,

${ }^{4}$ Contained $4.64 \% \mathrm{Ca}, 10.3 \% \mathrm{Mg}, 4,783 \mathrm{ppm} \mathrm{Fe}, 4,857 \mathrm{ppm} \mathrm{Cu}, 122$ ppm Co, 17,793 ppm Mn, 26,556 ppm Zn, 408 ppm I, 144 ppm Se, $545,000 \mathrm{IU} / \mathrm{kg}$ vitamin A, 109,000 IU/kg vitamin D, and 2,181 IU/kg vitamin E (Land O' Lakes, Inc, St. Paul, MN).

${ }^{5}$ Diamond V XP (Diamond V Mills, Inc, Cedar Rapids, IA).

${ }^{6}$ Zinpro (Zinpro Corp, Eden Prairie, MN).

${ }^{7}$ Contained 20,000 IU of vitamin E/kg.

of liquid feed to wheat straw. Wheat straw was also incubated alone to correct the degradation rates. Duplicate 5-g samples of each diet and liquid feeds absorbed on straw were weighed into $10 \times 20 \mathrm{~cm}$ Dacron bags (pore size $=53 \pm 10 \mu \mathrm{m}$; Ankom Products). Duplicate sample bags of each feed were placed into a larger nylon mesh bag $(36 \times 42 \mathrm{~cm})$ with a nylon zipper, soaked in $39^{\circ} \mathrm{C}$ water for $20 \mathrm{~min}$, and then introduced to the rumen.

Samples were introduced into the rumen in reverse order and removed simultaneously at the end of the experiment (Weakley et al., 1983). After incubation, all bags were rinsed with cold tap water. After draining for $4 \mathrm{~h}$, the Dacron bags were dried at $55^{\circ} \mathrm{C}$ for $48 \mathrm{~h}$. Residues of the feedstuffs after ruminal exposure were analyzed for DM and CP. Dry matter and CP disappearance were calculated by difference between the original amounts and the amounts remaining after ruminal fermentation. Digestion rates were calculated by regressing the natural log of disappearance on time of incubation.

Ruminally available DM and CP were estimated using the following equation (NRC, 2001): degradability percentage $=\mathrm{a}+\left\{\mathrm{b} \times\left[\mathrm{k}_{\mathrm{d}} /\left(\mathrm{k}_{\mathrm{d}}+\mathrm{k}_{\mathrm{p}}\right)\right]\right\}$ where $\mathrm{a}=$ amount soluble at $0 \mathrm{~h},(\%), \mathrm{b}=100-\mathrm{a},(\%), \mathrm{k}_{\mathrm{d}}=$ degradation rate of $\mathrm{b}(\% / \mathrm{h})$, and $\mathrm{k}_{\mathrm{p}}=$ passage rate from the rumen $(\% / \mathrm{h})$. Passage rate $(\% / \mathrm{h})$ was calculated using the NRC (2001) equation for concentrates: $\mathrm{k}_{\mathrm{p}}=2.904+1.375 \times$ $\mathrm{X}_{1}-0.020 \times \mathrm{X}_{2}$ where $\mathrm{k}_{\mathrm{p}}=$ rate of passage from the rumen $(\% / \mathrm{h}), \mathrm{X}_{1}=\mathrm{DMI}$, percentage of $\mathrm{BW}$, and $\mathrm{X}_{2}=$ concentrate, percentage of diet DM.

\section{Statistical Analysis}

Weekly means of DMI and milk yield during the final $2 \mathrm{wk}$ of each period were used for statistical analysis. Means were also calculated for data collected on d 26, 27, and 28 for milk composition and on d 27 and 28 for ruminal fluid and used for statistical analysis. The design of this experiment was a multiple Latin square (Mead et al., 2003) with a $2 \times 2$ arrangement of treatments. Cows were assigned to squares by parity; therefore, multiparous cows were randomly assigned across 2 of the Latin squares, and primiparous cows were assigned to the remaining square. Because all 3 squares were conducted simultaneously, the row effect (period) was assumed to be the same for all 3 squares. The 3 squares were combined to form a Latin rectangle (Mead et al., 2003). The data were analyzed using the MIXED procedures of SAS (SAS Institute, 2001).

Data were analyzed with the model:

$$
\begin{gathered}
\mathrm{Y}_{\mathrm{ijkl}}=\mu+\mathrm{P}_{\mathrm{i}}+\mathrm{C}_{\mathrm{j}\left(\mathrm{R}_{\mathrm{m}}\right)}+\mathrm{FS}_{\mathrm{k}}+\mathrm{SU}_{\mathrm{l}}+\left(\mathrm{FS}_{\mathrm{k}} \times \mathrm{SU}_{\mathrm{l}}\right) \\
+\mathrm{R}_{\mathrm{m}}+\left(\mathrm{FS}_{\mathrm{k}} \times \mathrm{R}_{\mathrm{m}}\right)+\left(\mathrm{SU}_{\mathrm{l}} \times \mathrm{R}_{\mathrm{m}}\right) \\
+\left(\mathrm{FS}_{\mathrm{k}} \times \mathrm{SU}_{\mathrm{l}} \times \mathrm{R}_{\mathrm{m}}\right)+\mathrm{e}_{\mathrm{ijklm}}
\end{gathered}
$$

where $\mu=$ overall mean, $P_{i}=$ effect of period ( $i=1$ to 4), $\mathrm{C}_{\mathrm{j}\left(\mathrm{R}_{\mathrm{m}}\right)}$ = effect of cow nested within parity $(\mathrm{j}=1$ to 12), $\mathrm{FS}_{\mathrm{k}}=$ effect of $\mathrm{FS}(\mathrm{k}=1$ to 2$), \mathrm{SU}_{\mathrm{l}}=$ effect of $\mathrm{SU}$ (l = 1 to 2$),\left(\mathrm{FS}_{\mathrm{k}} \times \mathrm{SU}_{\mathrm{l}}\right)=$ interaction of $\mathrm{FS}_{\mathrm{k}}$ and $\mathrm{SU}_{\mathrm{l}}$, $\mathrm{R}_{\mathrm{m}}=$ effect of parity $(\mathrm{m}=1$ to 2$),\left(\mathrm{FS}_{\mathrm{k}} \times \mathrm{R}_{\mathrm{m}}\right)=$ interaction of $\mathrm{FS}_{\mathrm{k}}$ and parity $\mathrm{m},\left(\mathrm{SU}_{\mathrm{l}} \times \mathrm{R}_{\mathrm{m}}\right)=$ interaction of $\mathrm{SU}_{\mathrm{l}}$ and parity $\mathrm{m},\left(\mathrm{FS}_{\mathrm{k}} \times \mathrm{SU}_{\mathrm{l}} \times \mathrm{R}_{\mathrm{m}}\right)=$ interaction of $\mathrm{FS}_{\mathrm{k}}$, $\mathrm{SU}_{\mathrm{l}}$, and parity $\mathrm{m}$, and $\mathrm{e}_{\mathrm{ijklm}}=$ random residual error. Cow within parity was the random effect. The model was designed to test the main effects of dietary inclusion of FS (NFS vs. FS) and SU (NSU vs. SU) and their interaction. Parity remained in the model for all variables. Differences because of parity are discussed in the text. Interactions with parity that were not significant were dropped from the model. Ruminal butyrate was the only variable with a significant $\mathrm{FS} \times \mathrm{SU} \times$ parity interaction. Furthermore, there were no interactions of the main effects with period for any variable; therefore they were not included in the model. Significance was declared at $P<0.05$, unless otherwise noted. 


\section{RESULTS AND DISCUSSION}

\section{Nutrient Content of Diets}

Ingredient and nutrient composition of diets are shown in Table 1. Diets were formulated to be isonitrogenous (16.0\%); however, analyses ranged from 15.7 to $16.5 \%$ CP. Soluble CP increased from $5.85 \%$ for NSU diets to $6.55 \%$ when SU was added to the diets. Total mixed diets were relatively similar in $\mathrm{NDF}, \mathrm{ADF}$, and ether extract. Nutrient composition of the FS product is presented in Table 2. Dry matter of the FS was $48.5 \%$. Crude protein concentration was $22.0 \%$ (DM basis) and consisted of mostly soluble protein (20.0\% DM basis). Total sugar concentration was $24.1 \%$ (DM basis) and consisted mostly of lactose (23.5\% DM basis).

\section{In Situ Study}

For the liquid FS and SU feedstuffs applied to straw, both DM and CP fully disappeared within the first 0.5 $\mathrm{h}$ of exposure to the rumen. This was not unexpected, because both are liquid products that are soluble in water. The FS product would be expected to solubilize quickly in the rumen. Although the SU fully disappeared from the Dacron bag within the first $0.5 \mathrm{~h}$ of exposure, it can still exhibit a slow release of ammonia $\mathrm{N}$ in the rumen. Decreased ammonia $\mathrm{N}$ release of liquid calcium chloride-bound urea has been previously demonstrated in vitro (Cass and Richardson, 1994). More recently, Huntington et al. (2006) demonstrated that this SU product effectively reduced the rate of ruminal ammonia $\mathrm{N}$ release compared with urea in steers. The slow release of ammonia $\mathrm{N}$ is supported in this experiment because ruminal ammonia concentrations did not increase for cows fed SU diets compared with NSU. Degradability percentages for the liquid FS and SU products applied to wheat straw were calculated to be greater than $93 \%$ with SU slightly higher than FS alone and FS and SU in combination.

Rates of degradation and ruminal degradabilities for DM and CP were also determined for the TMR of the experimental diets. Rumen passage rate using the concentrate formula was calculated to be $4.6 \% / \mathrm{h}$ (NRC, 2001). This was believed to be the best-fit equation because the diets contained both forages and concentrates. The rumen passage rate calculated in this study is slightly less than normal, which may be attributed to a DMI of $2.0 \%$ of BW. Rates of DM degradation were calculated to be $3.00,3.13,3.71$, and $3.15 \% / \mathrm{hr}$ for NSUNFS, NSU-FS, SU-NFS, and SU-FS diets, respectively. Dry matter degradabilities were 53.3, 56.0, 57.8, and $57.6 \%$ for the same diets. Rates of CP degradation were $3.46,3.38,4.12$, and $3.43 \% / \mathrm{hr}$ for NSU-NFS, NSU-FS, SU-NFS, and SU-FS diets, respectively. Crude protein degradabilities (as a percentage of total CP) were 57.4, $55.1,62.2$, and $57.8 \%$ for the same diets. The addition of FS numerically increased DM degradability by 1.2 percentage units (55.6 and $56.8 \%$ for NFS and FS, respectively). The addition of SU numerically increased CP degradability by 3.7 percentage units (56.3 and $60 \%$ for NSU and SU, respectively).

\section{DMI}

Dry matter intake, milk yield, and milk composition data are presented in Table 4. Dry matter intake was not affected by the inclusion of FS. Similar results for DMI were observed by Doreau et al. (1987) and Maiga et al. (1995) who reported that feeding milk (containing $10 \%$ fat and $13 \%$ lactose) or dried whey, respectively, to lactating dairy cattle was without effect on DMI. In contrast, in other studies where lactose was fed as either liquid (Pinchasov et al., 1982; DeFrain et al., 2004) or dried whey (Schingoethe and Rook, 1976; Casper and Schingoethe, 1986) to lactating dairy cattle, an increase in DMI was observed.

Dry matter intake of NSU diets was similar $(21.3 \mathrm{~kg} /$ d), whereas the inclusion of SU into the diet decreased DMI $(P=0.01 ; 19.8 \mathrm{~kg} / \mathrm{d})$. Decreased DMI resulting from feeding SU was similar to findings of Casper and Schingoethe (1986) in which cows fed urea had the lowest DMI. Some researchers suggest that the decreased DMI is because of the bitter taste of the urea (Huber and Kung, 1981). The mechanism of intake depression is not completely understood. When feeding urea, excess $\mathrm{N}$ not utilized in the rumen is excreted. Slow-release urea and other similar products attempt to achieve a slower rate of $\mathrm{N}$ release in the rumen and allow time to use $\mathrm{N}$ more efficiently while preventing ammonia toxicity. Slow-release urea compounds may also bind urea too tightly, rendering it unavailable in the rumen for hydrolysis. Although SU may be an improvement over unprotected urea, it may not always enhance animal performance compared with natural protein sources. Recently, Galo et al. (2003) fed a polymer-coated urea to dairy cows and observed no effect on DMI. However, the polymer coating was easily damaged, and therefore it was not effective in decreasing $\mathrm{N}$ excretion by the dairy cow (Galo et al., 2003).

There was an observed parity effect for DMI $(P=$ 0.05). Primiparous cows consumed $7.3 \mathrm{~kg} / \mathrm{d}$ less DM than the multiparous cows in this study $(24.2 \pm 1.9 \mathrm{vs}$. $16.9 \pm 2.7 \mathrm{~kg} / \mathrm{d}$, respectively). This is to be expected because primiparous cows generally have a lower DMI than multiparous cows. Average BW and BCS during the experiment were $656 \mathrm{~kg}(\mathrm{SD}=55)$ and $3.30(\mathrm{SD}=$ 0.28 ), respectively, across treatments with no differences across treatments (data not shown). 
Table 4. Least square means for intake, milk yield, and milk composition by dairy cows fed the experimental $\operatorname{diets}^{1}$

\begin{tabular}{|c|c|c|c|c|c|c|c|c|}
\hline \multirow[b]{2}{*}{ Item } & \multicolumn{2}{|c|}{ NSU } & \multicolumn{2}{|c|}{ SU } & \multirow[b]{2}{*}{ SEM } & \multicolumn{3}{|c|}{ Effect $^{2}(P$-value $)$} \\
\hline & NFS & FS & NFS & $\mathrm{FS}$ & & FS & SU & $\mathrm{FS} \times \mathrm{SU}$ \\
\hline DMI, kg/d & 21.3 & 21.3 & 19.7 & 20.0 & 1.72 & 0.75 & 0.01 & 0.85 \\
\hline Milk, kg/d & 26.7 & 25.5 & 26.8 & 25.6 & 1.33 & 0.06 & 0.83 & 0.97 \\
\hline ECM, kg/d & 28.2 & 27.9 & 28.9 & 27.9 & 1.45 & 0.37 & 0.61 & 0.59 \\
\hline ECM/DMI & 1.35 & 1.35 & 1.53 & 1.47 & 0.07 & 0.52 & 0.01 & 0.58 \\
\hline Milk fat, $\%$ & 4.18 & 4.51 & 4.36 & 4.48 & 0.11 & 0.002 & 0.29 & 0.12 \\
\hline Milk fat, kg/d & 1.12 & 1.15 & 1.17 & 1.15 & 0.06 & 0.83 & 0.47 & 0.39 \\
\hline Milk true protein, \% & 3.73 & 3.75 & 3.75 & 3.74 & 0.07 & 0.78 & 0.88 & 0.64 \\
\hline Milk true protein, $\mathrm{kg} / \mathrm{d}$ & 0.99 & 0.96 & 1.00 & 0.95 & 0.04 & 0.07 & 0.84 & 0.83 \\
\hline Milk lactose, $\%$ & 4.85 & 4.79 & 4.84 & 4.80 & 0.04 & 0.05 & 0.86 & 0.81 \\
\hline Milk lactose, kg/d & 1.30 & 1.22 & 1.30 & 1.23 & 0.07 & 0.03 & 0.82 & 0.91 \\
\hline Milk TS, \% & 13.7 & 14.0 & 13.9 & 13.9 & 0.15 & 0.05 & 0.44 & 0.08 \\
\hline Milk TS, kg/d & 3.69 & 3.57 & 3.73 & 3.54 & 0.18 & 0.08 & 0.94 & 0.66 \\
\hline $\mathrm{SCC}, \times 10^{3} / \mathrm{mL}$ & 97 & 84 & 53 & 67 & 20 & 0.99 & 0.03 & 0.33 \\
\hline Milk urea $\mathrm{N}, \mathrm{mg} / \mathrm{dL}$ & 13.2 & 12.7 & 13.6 & 13.4 & 0.52 & 0.31 & 0.12 & 0.74 \\
\hline
\end{tabular}

\footnotetext{
${ }^{1} \mathrm{NSU}=$ No slow-release urea; $\mathrm{SU}=$ slow-release urea; $\mathrm{FS}$ = fermentable sugar; NFS = no fermentable sugar.

${ }^{2} \mathrm{FS}=$ Effect of fermentable sugar (NFS vs. FS); $\mathrm{SU}=$ effect of slow-release urea (NSU vs. SU), $\mathrm{FS} \times \mathrm{SU}=$ interaction of FS and SU.
}

\section{Milk Production and Composition}

Milk yield tended $(P=0.06)$ to decrease in cows fed diets containing FS compared with NFS (25.5 vs. 26.7 $\mathrm{kg} / \mathrm{d}$, respectively). Similar results were reported by Bowman and Huber (1967) and Schingoethe et al. (1976) in which substitution of whey for ground-shelled corn resulted in slightly decreased milk yields. The addition of SU had no effect on daily milk yield, which is in agreement with the results of Galo et al. (2003). A parity effect $(P=0.02)$ was also observed for milk yield, where multiparous cows produced $6.8 \mathrm{~kg} / \mathrm{d}$ more milk than primiparous cows $(29.5 \pm 1.4 \mathrm{vs} .22 .7 \pm 2.0 \mathrm{~kg}$, respectively).

Milk fat percentage was greater $(P=0.002)$ for cows fed FS compared with NFS (4.49 vs. $4.27 \%$, respectively). These results agreed with previous research that demonstrated that cows fed dietary lactose (Bowman and Huber, 1967) or whey (Schingoethe, 1976; Schingoethe et al., 1976; Schingoethe and Skyberg, 1981) increased milk fat percentages. This increase in milk fat percentage may be attributed to observed increases in molar proportions of ruminal butyrate (Table 5). Butyrate is metabolized to BHBA by ruminal epithelium and is subsequently used as a precursor for milk fatty acid synthesis (Palmquist et al., 1969). Because of the trend for lower daily milk yield, milk fat yield was not affected by treatment even though FS had a significantly higher milk fat percentage. Milk fat percentage was unaffected by the addition of SU and is in accordance with other studies in which feeding urea had no significant effect on milk fat percentage (Van Horn et al., 1967; Wohlt and Clark, 1978; Galo et al.,
2003). In contrast, Casper and Schingoethe (1986) reported an unexplained decrease in milk fat percentage for cows fed urea.

True protein percentage and MUN were not affected by dietary treatment (Table 4). Replacing corn and soybean meal with FS did not affect true protein percentage, in agreement with experiments in which whey was added to the diet (Bowman and Huber, 1967; Pinchasov et al., 1982; DeFrain et al., 2004). However, when dried whey was fed in place of shelled corn in diets of latelactation Holstein cows, milk protein percentage was greater compared with control-fed cows (3.95 and $3.80 \%$, respectively; Schingoethe et al., 1976). Differences in response to feeding whey observed in that study could possibly be attributed to a later stage of lactation (180 DIM) and lower milk yields $(16.5 \mathrm{~kg} / \mathrm{d})$ than compared with the present study $(\mathrm{DMI}=117$ at the start of the experiment; milk yield $=25.5 \mathrm{~kg} / \mathrm{d}$ ). In this experiment true protein yield tended to decrease $(P=0.07)$ in cows fed FS. The decrease in true protein yield can be attributed to the trend for decreased milk yield in those cows. Replacement of soybean meal with SU did not alter true protein percentage or yield or MUN, demonstrating that SU can be an alternative source of $\mathrm{N}$ in dairy cow diets without causing inefficient use of $\mathrm{N}$.

The percentage of lactose in milk from cows fed FS was lower $(P=0.05)$ than that for cows fed NFS. Reported effects of diets on milk lactose concentrations are few, and previous research on feeding sugars such as lactose (DeFrain et al., 2004; 2006) did not demonstrate similar effects. Although not highly correlated, a generally negative relationship between milk fat and 
Table 5. Least square means for rumen fermentation parameters of dairy cows fed the experimental diets ${ }^{1}$

\begin{tabular}{|c|c|c|c|c|c|c|c|c|}
\hline \multirow[b]{2}{*}{ Item } & \multicolumn{2}{|c|}{ NSU } & \multicolumn{2}{|c|}{ SU } & \multirow[b]{2}{*}{ SEM } & \multicolumn{3}{|c|}{ Effect $^{2}(P$-value $)$} \\
\hline & NFS & FS & NFS & FS & & FS & SU & $\mathrm{FS} \times \mathrm{SU}$ \\
\hline $\mathrm{NH}_{3} \mathrm{~N}, \mathrm{mg} / \mathrm{dL}$ & 5.87 & 4.99 & 5.93 & 5.99 & 0.89 & 0.64 & 0.54 & 0.59 \\
\hline Acetate, $\%$ & 62.9 & 62.9 & 63.0 & 63.4 & 0.62 & 0.72 & 0.63 & 0.76 \\
\hline Propionate, \% & 21.7 & 20.7 & 21.8 & 21.1 & 0.53 & 0.04 & 0.63 & 0.82 \\
\hline Isobutyrate, \% & 1.54 & 1.19 & 1.17 & 1.10 & 0.14 & 0.13 & 0.11 & 0.30 \\
\hline Butyrate, ${ }^{3} \%$ & 10.6 & 12.2 & 10.6 & 11.6 & 0.28 & $<0.001$ & 0.21 & 0.21 \\
\hline Isovalerate, \% & 1.35 & 1.46 & 1.42 & 1.36 & 0.08 & 0.79 & 0.83 & 0.25 \\
\hline Valerate, \% & 1.88 & 1.54 & 1.95 & 1.51 & 0.43 & 0.37 & 0.96 & 0.91 \\
\hline Total VFA, mM & 56.5 & 51.5 & 53.6 & 46.4 & 5.82 & 0.29 & 0.48 & 0.85 \\
\hline Acetate:propionate & 2.94 & 3.09 & 2.92 & 3.06 & 0.10 & 0.07 & 0.79 & 0.95 \\
\hline
\end{tabular}

${ }^{1} \mathrm{NSU}=$ No slow-release urea; $\mathrm{SU}=$ slow-release urea; FS = fermentable sugar; NFS = no fermentable sugar.

${ }^{2} \mathrm{FS}=$ Effect of fermentable sugar (NFS vs. FS); $\mathrm{SU}=$ effect of slow-release urea (NSU vs. SU), FS $\times \mathrm{SU}=$ interaction of FS and SU.

${ }^{3}$ Interaction of FS $\times$ SU $\times$ parity $(P<0.03)$.

lactose concentrations has been noted (Jenness and Patton, 1959), and this relationship appears to be supported by increased milk fat concentrations observed in this experiment. Furthermore, decreased production of ruminal propionate as observed in this experiment provides less precursor for glucose and subsequent lactose synthesis. Although lactose is commonly considered to be the major compound regulating milk osmolality, in light of decreased propionate production and milk output, the role of lactose in this function may be diminished relative to other compounds.

Milk TS percentage was greater $(P<0.05)$ for cows fed FS, primarily due to the increase in milk fat percentage. Yield of TS, however, tended to be greater for cows fed NFS as a reflection of greater milk yield of these cows. The addition of SU had no overall impact on milk component composition.

Energy-corrected milk yields were similar for all 4 diets with an average of $28.2 \mathrm{~kg} / \mathrm{d}$. Although cows fed diets containing FS tended to produce less milk, ECM yield was similar to the other diets as a result of increased milk fat percentage $(P=0.002)$. Multiparous cows also produced $7.9 \mathrm{~kg} / \mathrm{d}$ more ECM than primiparous cows in this study ( $33.3 \pm 1.5$ vs. $24.3 \pm 2.1 \mathrm{~kg} / \mathrm{d}$; $P=0.01$ ).

The addition of FS in diets did not affect feed efficiency (ECM/DMI). Whey-containing diets are noted to slightly improve feed efficiency (Schingoethe, 1976); however, this was not observed in the present study because of the tendency for lower milk production from cows fed FS. Feed efficiency, however, was greater $(P=$ 0.01 ) for cows fed SU compared with NSU (1.50 vs. 1.35 , respectively). No studies have reported feed efficiencies for dairy cows fed SU. In research using feedlot steers, diets containing calcium chloride-bound SU has been shown to improve feed efficiency (Cass et al., 1995; Duff et al., 2000). Not all SU products are the same.
Tedeschi et al. (2002) fed a polymer-coated SU to growing steers and noted no improvement in feed conversion when it was substituted for urea at levels normally found in feedlot diets. The improvement in feed efficiency reported here is consistent with previous research dealing with urea supplementation. This improvement would be expected because cows consumed less DM and there was no drop in daily milk yield for cows fed SU. There were no interactions of treatments with parity in this experiment, but primiparous cows tended $(P=0.08)$ to be slightly more efficient in converting feed to milk than multiparous cows $(1.48 \pm 0.07$ vs. $1.37 \pm 0.10$, respectively).

\section{Rumen Fluid}

Concentrations of ammonia $\mathrm{N}$ and total VFA, and ruminal proportions of acetate, isobutyrate, isovalerate, and valerate were not different among dietary treatments (Table 5). Ruminal ammonia N did not differ across diets, suggesting that SU did exhibit slow-release properties as demonstrated by Huntington et al. (2006). Ruminal fluid from cows fed FS diets contained less $(P=0.04)$ propionate than from cows fed NFS (20.8 vs. 21.8 molar $\%$, respectively). The decrease in ruminal molar percentage of propionate in cows fed whey agree with observations reviewed by Schingoethe (1976) and was attributed to feeding lactose in the diet. As a result of the decreased ruminal propionate in cows fed the FS diets, the acetate topropionate ratio tended $(P=0.07)$ to be greater in cows fed FS. The increase in acetate to propionate ratio may indicate altered rumen fermentation that may have contributed to the increase in milk fat percentage in the cows fed FS.

Feeding FS increased $(P<0.001)$ ruminal butyrate proportions by 1.3 percentage units over NFS (11.9 vs. 10.6 molar \%, respectively). In a review of whey feeding 
to dairy cows, Schingoethe (1976) indicated that the consistent increase in ruminal butyrate proportions was because this VFA is the end product of lactose fermentation. These findings are also in agreement with research conducted by numerous researchers (Schingoethe et al., 1976; Schingoethe and Skyberg, 1981; Casper and Schingoethe, 1986; Chamberlain et al., 1993; Susmel et al., 1995; DeFrain et al., 2004). Chamberlain et al. (1993) and Susmel et al. (1995) observed greater ruminal butyrate concentrations (14.5 and $13.4 \%$, respectively) than what was observed in this study for FS (11.9\%). This may be attributed to the use of deproteinized and partially delactosed whey permeate with corn steep liquor used in this study. As a result, less lactose may have been fed compared with the amount present in whole whey.

The ruminal molar percentage of butyrate demonstrated a $\mathrm{FS} \times \mathrm{SU} \times$ parity effect $(P=0.03)$. Ruminal molar percentages of butyrate were 10.3, 12.8, 10.7, and 11.5 for multiparous cows and 10.9, 11.6, 10.6, and 11.7 for primiparous cows fed NSU-NFS, NSU-FS, SUNFS, and SU-FS diets, respectively. The interaction was largely attributable to the relatively greater molar proportions of $12.8 \%$ butyrate in multiparous cows fed the NSU-FS diet. The interaction observed between FS $\times \mathrm{SU} \times$ parity in this study is not well understood, but could be related to relative DMI of primiparous vs. multiparous cows.

\section{CONCLUSIONS}

Results from the present study show that the addition of FS to diets of dairy cows increased ruminal butyrate concentrations and milk fat percentages. The addition of an SU reduced intake without affecting milk production resulting in improved feed efficiency. The addition of FS in combination with a slow-release nitrogen source did not demonstrate a synergistic response in this study. Coproducts from the corn milling and cheese processing industries and SU can replace corn and soybean meal in diets of lactating dairy cows and improve the efficiency of milk production.

\section{ACKNOWLEDGMENTS}

The authors express appreciation to Davisco Foods International (Le Sueur, MN), Midwest Ag Enterprises (Marshall, MN), and XF Enterprises, Inc. (Hereford, TX) for partial financial support for this project and to personnel at the South Dakota State University Dairy Teaching and Research Farm for the feeding and care of the animals.

\section{REFERENCES}

AOAC. 1997. Official Methods of Analysis. 16th ed. Association of Official Analytical Chemists. Gaithersburg, MD.

Bowman, R. L., and J. T. Huber. 1967. Effect of dietary lactose on milk composition and rumen volatile fatty acids. J. Dairy Sci. 50:579-581.

Broderick, G. A., and J. H. Kang. 1980. Automated simultaneous determination of ammonia and total amino acids in ruminal fluid and in vitro media. J. Dairy Sci. 63:64-75.

Casper, D. P., and D. J. Schingoethe. 1986. Evaluation of urea and dried whey in diets of cows during lactation. J. Dairy Sci. 69:1346-1354.

Cass, J. L., and C. R. Richardson. 1994. In vitro ammonia release from urea/calcium compounds as compared to urea and cottonseed meal. Technical Report No. T-5-342. Texas Tech University, Lubbock.

Cass, J. L., C. R. Richardson, R. C. Albin, and M. F. Miller. 1995. Effects of slow ammonia release urea/calcium compound on performance and carcass characteristics of feedlot steers. Technical report No. T-5-356.Texas Tech University, Lubbock.

Chamberlain, D. G., S. Robertson, and J. Choung. 1993. Sugars versus starch as supplements to grass silage: Effects on ruminal fermentation and the supply of microbial protein to the small intestine, estimated from the urinary excretion of purine derivatives, in sheep. J. Sci. Food Agric. 63:189-194.

DeFrain, J. M., A. R. Hippen, K. F. Kalscheur, and D. J. Schingoethe. 2004. Feeding lactose increases ruminal butyrate and plasma $\beta$ hydroxybutyrate in lactating dairy cows. J. Dairy Sci. 87:24862494.

DeFrain, J. M., A. R. Hippen, K. F. Kalscheur, and D. J. Schingoethe. 2006. Feeding lactose to increase ruminal butyrate and the metabolic status of transition dairy cows. J. Dairy Sci. 89:267-276.

Doreau, M., D. Bauchart, and A. Kindler. 1987. Effect of fat and lactose supplementation on digestion in dairy cows. 1. Nonlipid components. J. Dairy Sci. 70:64-70.

Duff, G. C., D. A. Walker, K. J. Malcolm-Callis, M. W. Wiseman, J. D. Rivera, M. L. Galyean, and T. H. Montgomery. 2000. Effects of a slow-release urea product on feedlot performance and carcass characteristics of beef steers. J. Anim. Sci. 78(Suppl. 2):115. (Abstr.)

Galo, E., S. M. Emanuele, C. J. Sniffen, J. H. White, and J. R. Knapp. 2003. Effects of a polymer-coated urea product on nitrogen metabolism in lactating Holstein dairy cattle. J. Dairy Sci. 86:21542162.

Huber, J. T., and L. Kung, Jr. 1981. Protein and nonprotein nitrogen utilization in dairy cattle. J. Dairy Sci. 64:1170-1195.

Huntington, G. B., D. L. Harmon, N. B. Kristensen, K. C. Hanson, and J. W. Spears. 2006. Effects of a slow-release urea source on absorption of ammonia and endogenous production of urea by cattle. Anim. Feed Sci. Technol. doi:10.1016/j.anifeedsci.2006. 01.012

Jenness, R., and S. Patton. 1959. Principles of Dairy Chemistry. John Wiley and Sons, New York, NY.

Licitra, G., T. M. Hernandez, and P. J. Van Soest. 1996. Standardization of procedures for nitrogen fractionation of ruminant feeds. Anim. Feed Sci. Technol. 57:347-358.

Maiga, H. A., D. J. Schingoethe, and F. C. Ludens. 1995. Evaluation of diets containing supplemental fat with different sources of carbohydrates for lactating dairy cows. J. Dairy Sci. 78:11221130 .

Mead, R., R. N. Curnow, and A. M. Hasted. 2003. Multiple Latin square designs. Pages 81-84 in Statistical Methods in Agriculture and Experimental Biology. 3rd ed. Chapman and Hall/CRC, Boca Raton, FL.

NRC. 2001. Nutrient Requirements of Dairy Cattle. 7th rev. ed. Natl. Acad. Sci., Washington, DC.

Palmquist, D. L., C. L. Davis, R. E. Brown, and D. S. Sachan. 1969. Availability and metabolism of various substrates in ruminants. V. Entry rate into the body and incorporation into milk fat of D(-)betahydroxybutyrate. J. Dairy Sci. 52:633-638. 
Pinchasov, Y., A. Hasdai, S. Gordin, D. Katznelson, and R. Volcani. 1982. Performance of high-yielding dairy cows fed liquid whey. J. Dairy Sci. 65:28-36.

SAS Institute. 2001. SAS User's Guide. Statistics, Version 8 ed. SAS Institute, Inc., Cary, NC.

Schingoethe, D. J. 1976. Whey utilization in animal feeding: A summary and review. J. Dairy Sci. 59:556-570.

Schingoethe, D. J., F. Ludens, W. L. Tucker, and S. K. Dash. 1976. Evaluation of dried whey in concentrate mixtures for lactating dairy cows. J. Dairy Sci. 59:1466-1470.

Schingoethe, D. J., and J. A. Rook. 1976. Ration digestibility and mineral balance in lactating cows fed rations containing dried whey. J. Dairy Sci. 59:992-996.

Schingoethe, D. J., and E. W. Skyberg. 1981. Lactational response to dried whey in concentrate mixture fed to dairy cows. J. Dairy Sci. 64:135-139.

Susmel, P., M. Spanghero, C. R. Mills, and B. Stefanon. 1995. Rumen fermentation characteristics and digestibility of cattle diets containing different whey:maize ratios. Anim. Feed Sci. Technol. 53:81-89.

Tedeschi, L. O., M. J. Baker, D. J. Ketchen, and D. G. Fox. 2002. Performance of growing and finishing cattle supplemented with a slow-release urea product and urea. Can J. Anim. Sci. 82:567-573.
Tyrrell, H. F., and J. T. Reid. 1965. Prediction of the energy value of cows milk. J. Dairy Sci. 48:1215-1223.

Van Horn, H. H., C. F. Foreman, and J. E. Rodriquez. 1967. Effect of high-urea supplementation on feed intake and milk production of dairy cows. J. Dairy Sci. 50:709-714.

Van Soest, P. J., J. B. Robertson, and B. A. Lewis. 1991. Methods for dietary fiber, neutral detergent fiber, and nonstarch polysaccharides in relation to animal nutrition. J. Dairy Sci. 74:35833597.

Virtanen, A. I. 1966. Milk production of cows on protein-free feed. Science 153:1603-1614.

Weakley, D. C., M. D. Stern, and L. D. Satter. 1983. Factors affecting disappearance of feedstuffs from bags suspended in the rumen. J. Anim. Sci. 56:493-507.

Wildman, E. E., G. M. Jones, P. E. Wagner, R. L. Bowman, H. F. Troutt, Jr., and T. N. Lesch. 1982. A dairy cow body condition scoring system and relationship to selected production characteristics. J. Dairy Sci. 65:495-501.

Wohlt, J. E., and J. H. Clark. 1978. Nutritional value of urea versus preformed protein for ruminants. I. Lactation of dairy cows fed corn based diets containing supplemental nitrogen from urea and/ or soybean meal. J. Dairy Sci. 61:902-915. 